\title{
Paper 10-21: CHANGE IN EDENIAN TRIARTHRUS SPECIES ALONG A DEPTH GRADIENT IN THE TACONIC FORELAND BASIN, PA
}

\section{TV] MCCLURE, Timothy C. and BUSCH, Richard M., Department of Earth and Space Sciences, West Chester University, West Chester, PA 19383 WEST CHESTER
U N I V E R S I T Y}

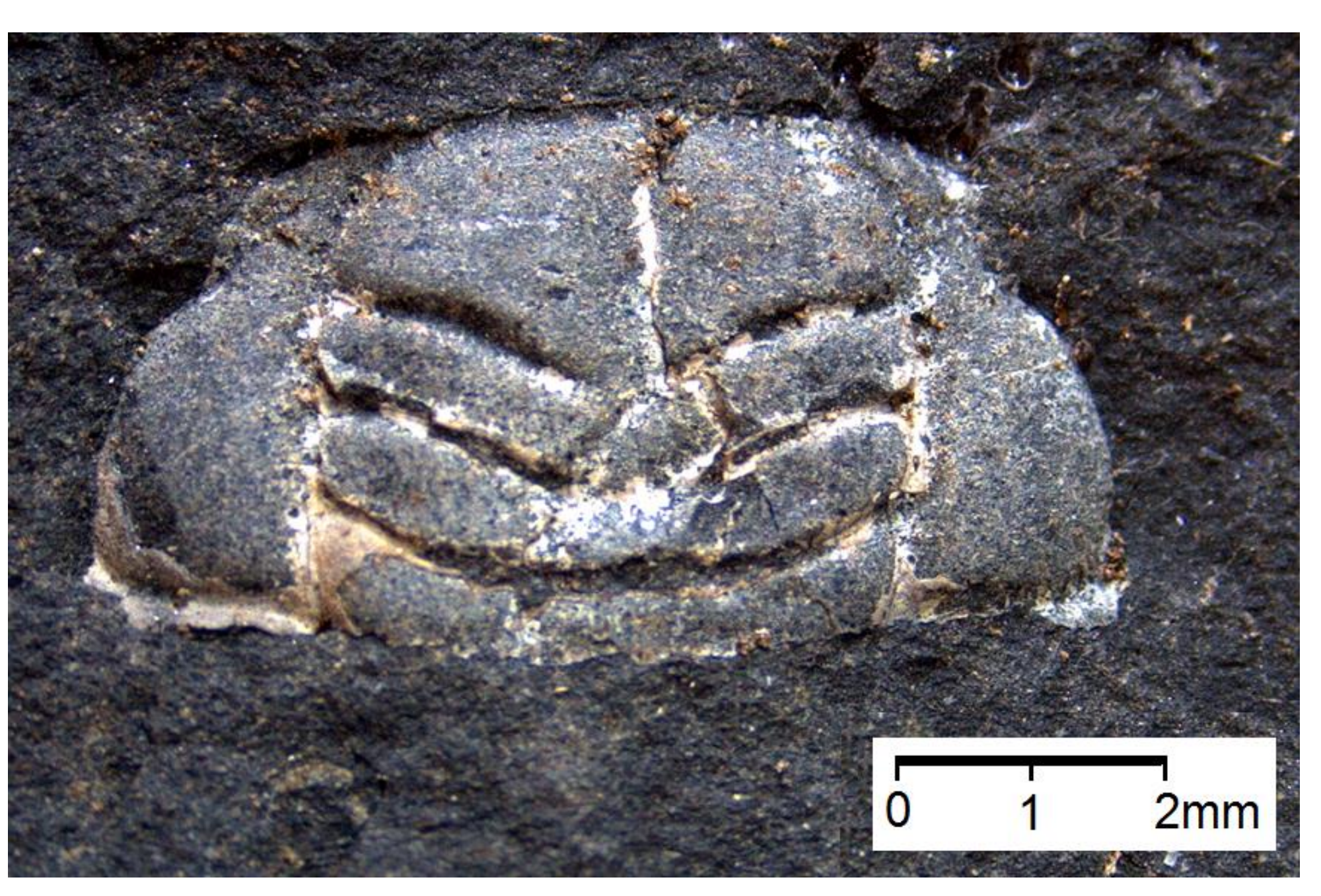

Figure 4: T. beckii, Antes Fm Bellefonte, PA.

Triart

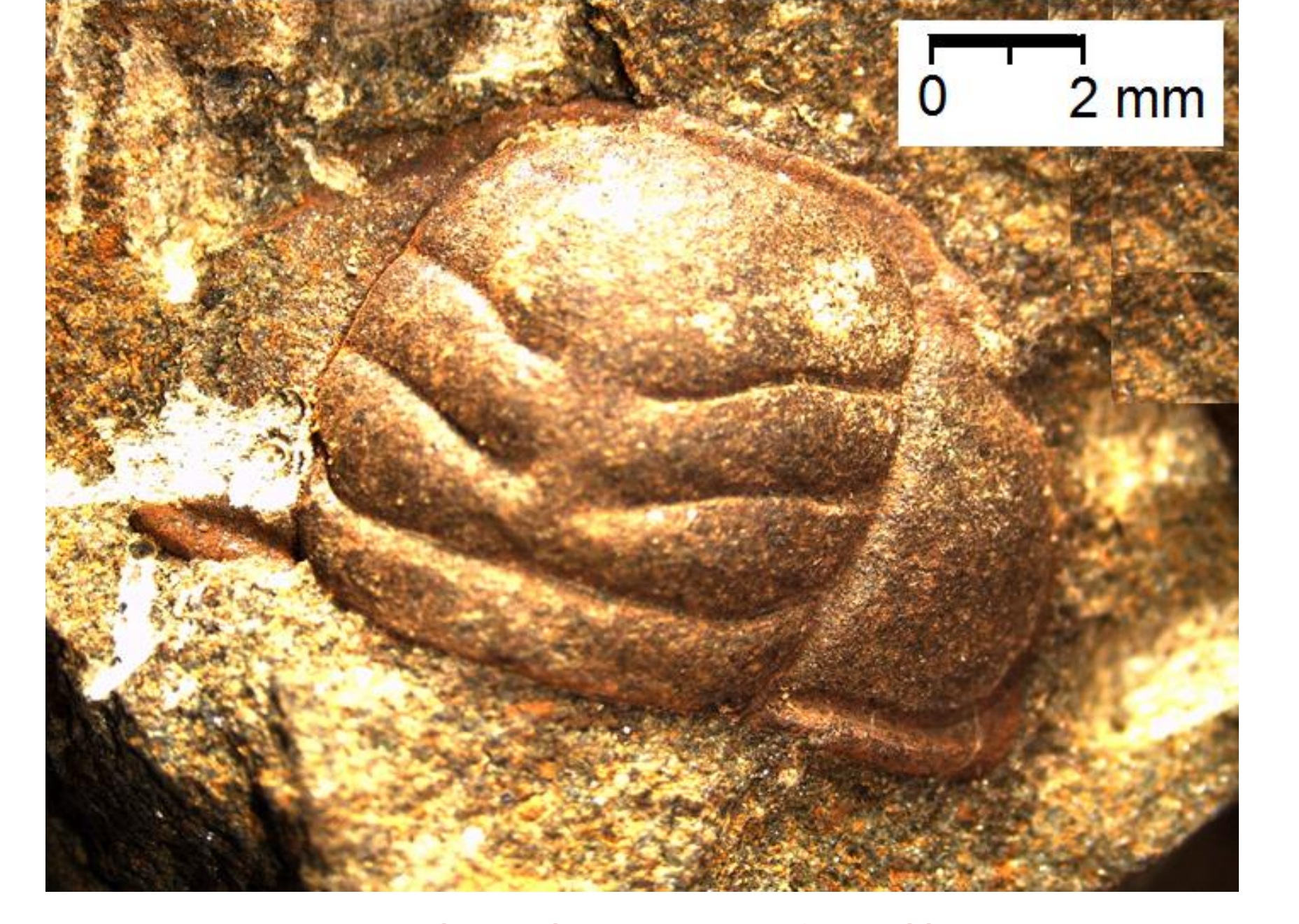
swe 3: T. beckii, Reedsville $\mathrm{Fm}$ atara Gap, PA.

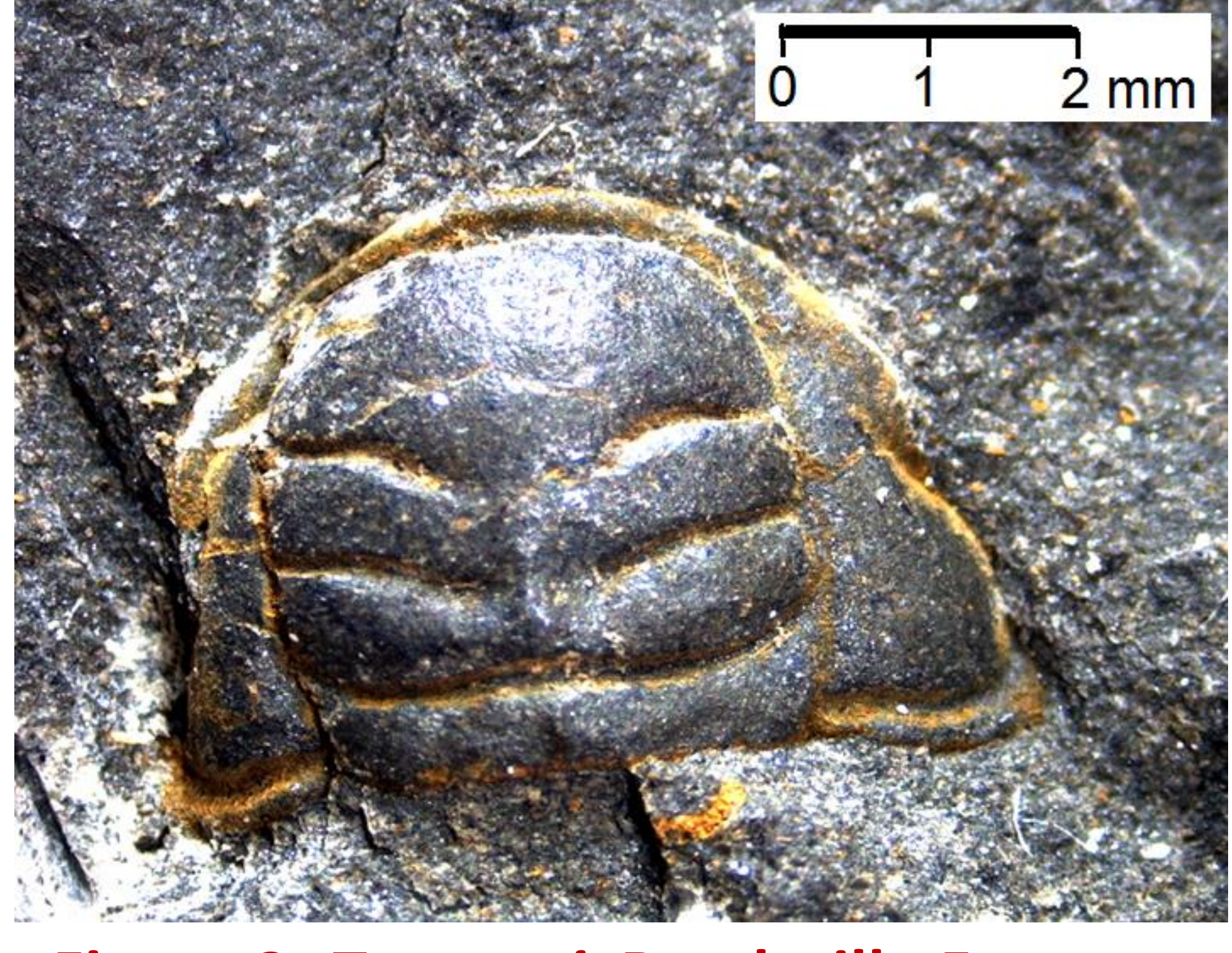

Figure 2: T. eatoni, Reedsville Fm, pecies based on an in-depth literature review and identification of new distinct characteristics.

\section{New Distinct Characteristics}

Triarthrus beckii has a short palpebral lobe that terminates or barely exceeds at a line that intersects the distal ends of the S2 furrows plus a maximum of 16 fixigenae/cephalon, through the abaxial ends of the $\$ 1$ lateral glabella furrows, intersect (sag.) on the anterior glabellar furrow/border of the cephalon. Triarthrus eatoni has a long palpebral lobe that terminates at a line that intersets the distal ends of the S1 furrow plus a maximum of 14 thoracic segments (Figure 1). Lines drawn from the posterolateral angles of the figenae/cephalon, through the abaxial ends of the $\mathrm{S1}$ lateral glabellar furrows, intersect (sag.) on the frontal lobe of the glabella. Shape of the secies but posess riable in flatent/shead secins.

Ludvigsen \& Tuffnell (1994) and Tuffnell \& Ludvigsen (1984) characterized beckil as having an anteriorly rounded, barrel-shaped glabella and eatoni as having a less anteriorly rounded, parallel sided glabella. Ruedemann (1926) aso charactenzed eatoni has having a glabella that was longer than wide while beckii with a glabella that was equally long as wide. According to Tuffnell \& the cot marin. While we agree with these assessments, we found these features proved unreliable in specimens showing deformation. A literature review and study of New York and Pennsylvania specimens has revealed that beckii has a The segments. While we acknowledge the value of this characteristic, the lack of full body specimens in our localities limited its usefulness. The new distinct characteristics, as highighted in Figure 1 , were the primary method of identification of
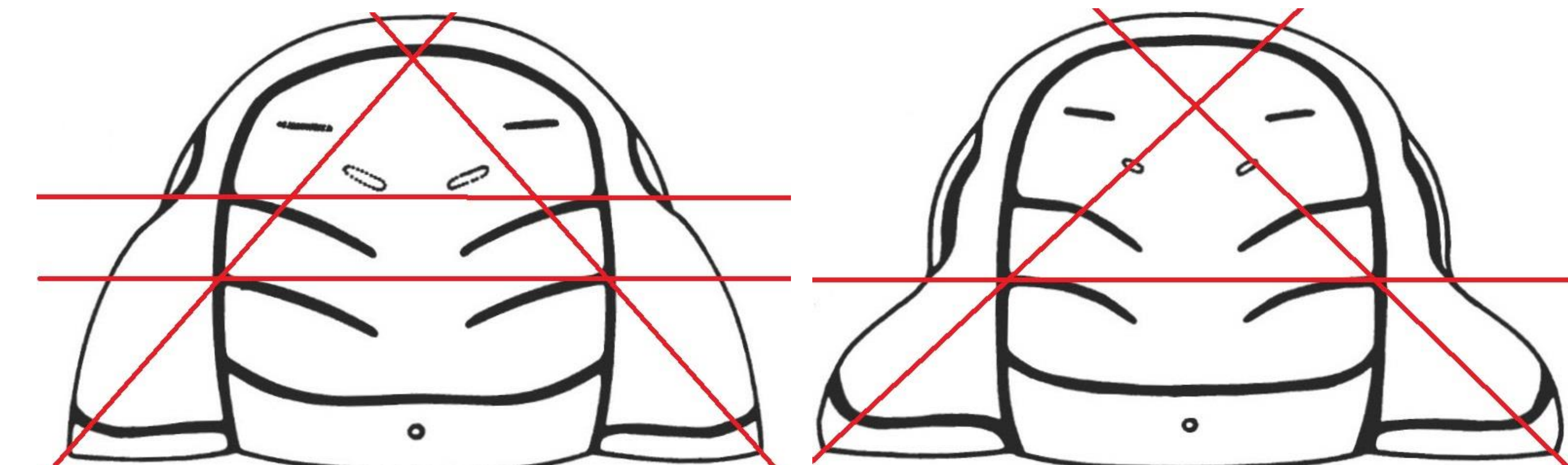

Figure 1: Morphology of T. beckii (left) and eatoni (right) adapted and modified Figure 1: Morphology of T. beckii (left) and eatoni (right) adapted and modified
from Ludvigsen \& Tuffnell's (1994) Figures 14 \& 15 to show both their (black) and from Ludvigsen $\&$ Tuffnell's (1994) Figures $14 \& 15$ to show both their
our new distinctive characteristics (red). Note red lines drawn from the posterolateral angles of the fixigenae/cephalon and through the abaxial ends of the S1 lateral glabellar furrows on both figures. Also drawn are lines that intersec the $\$ 1$ furrow on eatoni (right) and the $\$ 1$ and $S 2$ furrows on beckiil (left).

Fisher (1977) identified a New York $T$. beckii chronozone that he regarded as coeval with the Orthograptus reudemann graptolite zone and younger $T$. eatoni chronozone that he regarded as coeval with the Diplacanthograptus spiniferous graptolite zone. Ludvigsen and Tuffnell (1994) regarded New York beckil as Late Franklin/Sherman through Early Maysville age. We now is cort hectir datum is concealed and their last occurrence datum occurs just below the regional unconformity with the overlyin Middle Eden age (Dix and Al-Dulami 2011; Fisure 5). In the Antes Shale, the beckii chronezen is of Late Sherman through Middle Eden age, $O$. reudemanni throun $D$. spiniferous graptolite zones (Beares at a 2002). T beckii has also been reported from the Bromley Fulton, and Alexandria shales of Ohio; rocks of Late Sherman through Middle Eden age (Davis, 1981, Brett, Algeo, and McLaughlin, 2008). So the beckii zone in Pennsylvania and Ohio is of Late Sherman through Middle Eden age.
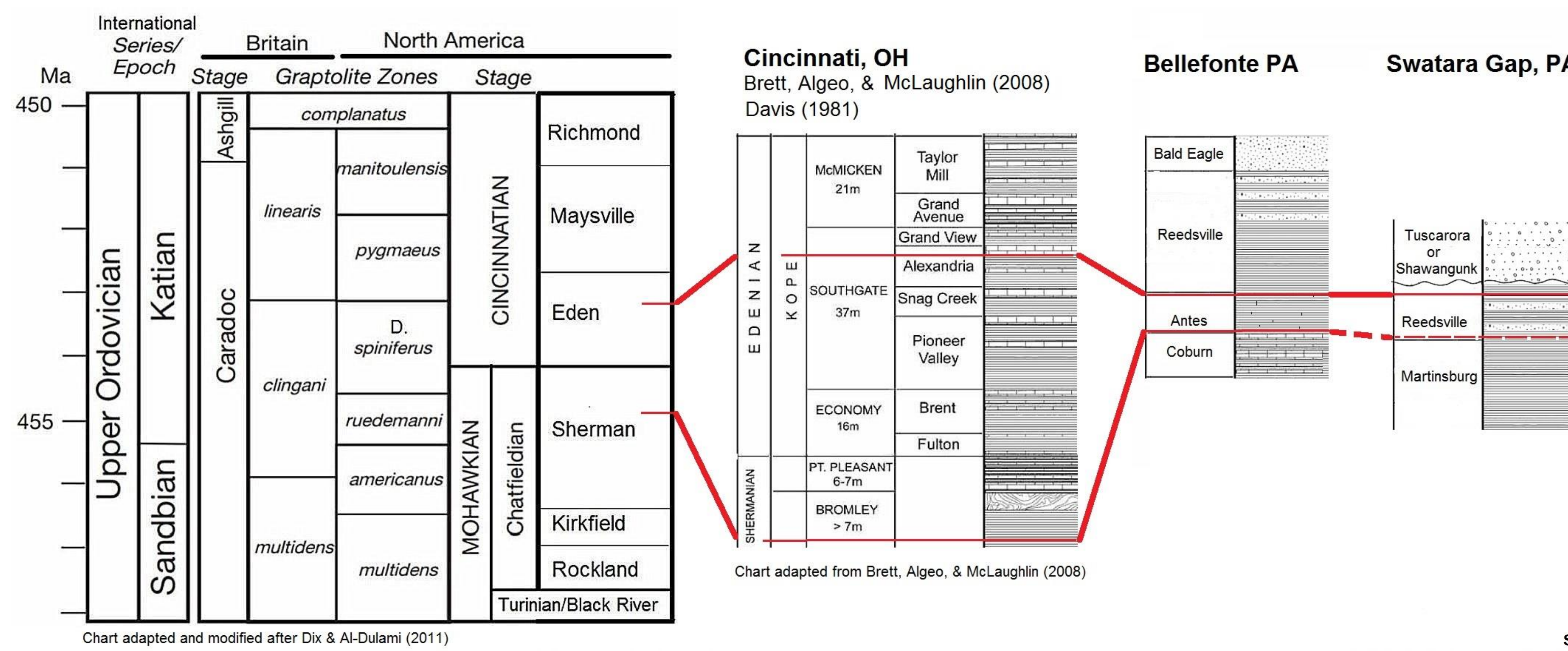

Figure 5: T. beckii chronozone in Ohio.

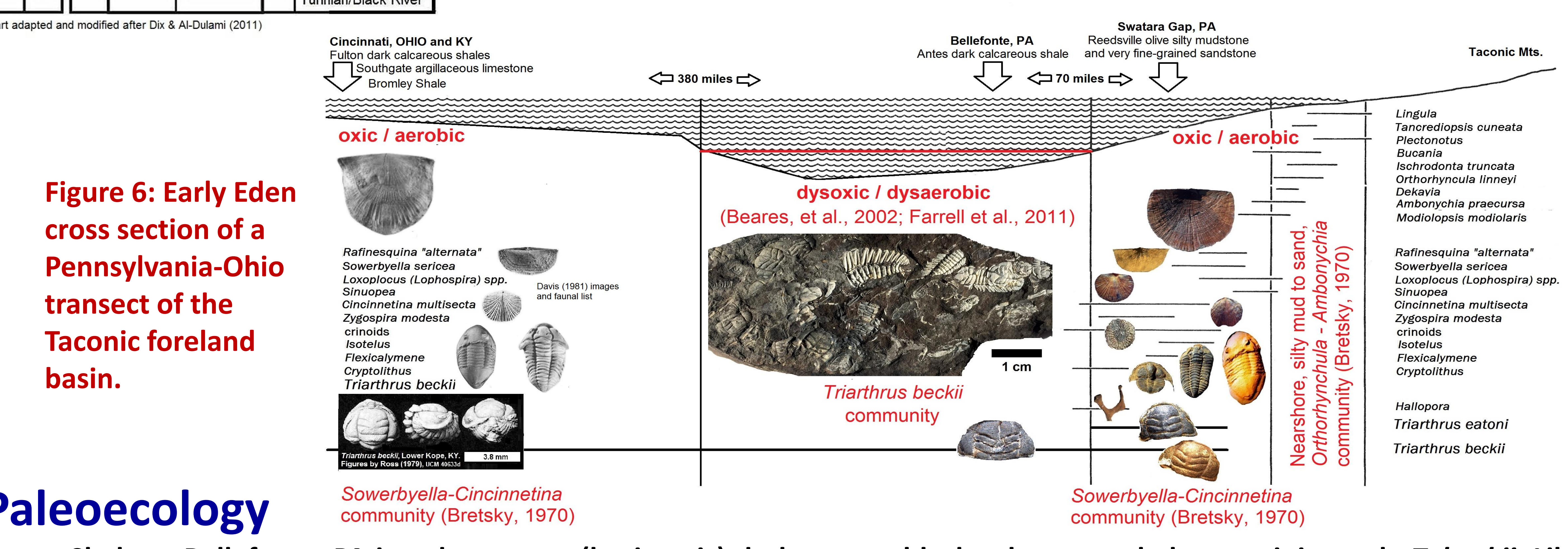

4. Paleoecology Sowerbyella-Cincinneting
community (Bretsyy, 19

The Antes Shale at Bellefonte, PA is a deep ramp (basin axis) dark-gray to black calcareous shale containing only T. beckii. Like other reported occurrences of beckii, it was the dominant member of a low diversity community that lived under conditions that others described as dysaerobic/dysoxic. At Swatara Gap, the Reedsville Formation contains both eatoni and beckii. This is the first record of both species occurring in the same location, lithology (olive gray, micaceous, silty mudstone interbedded with cross-laminated siltstone and very fine-grained sandstone) and community (high-diversity fauna living under oxic/aerobic
conditions). T. eatoni and beckii lived together as members of Bretsky's (1970) diverse, shelly, Sowerbyella-Cincinnetina community (Figure 6) in the oxic/aerobic lower shoreface environment of eastern Pennsylvania while only beckii (larger and more abundant) lived 70 miles west (Belleforie) as the dominant member of the low diversity triarthrus community living in a deeper (below wave base) dysaerobic/dysoxic basin-axis environment. Continuing $\mathbf{3 8 0}$ miles west of Bellefonte, to Cincinnati,
5. Population Change

Figure 7 shows the size comparisons of coeval Triarthrus from Swatara Gap and Bellefonte, PA. Although the mode is similar for both populations, there is a clear difference in size distribution. Larger specimens occur in the the Antes ecosystem at where they also are more abundant. Therefore, several instars larger than in the coeval Reedsville ecosystem at Swata Gap; although, the reason for this is not clear. The result is an increase maximum size of Tiarthrus along a depth gradient in the Taconic foreland .

Triarthrus of the Reedsville Fm, Swatara Gap, PA

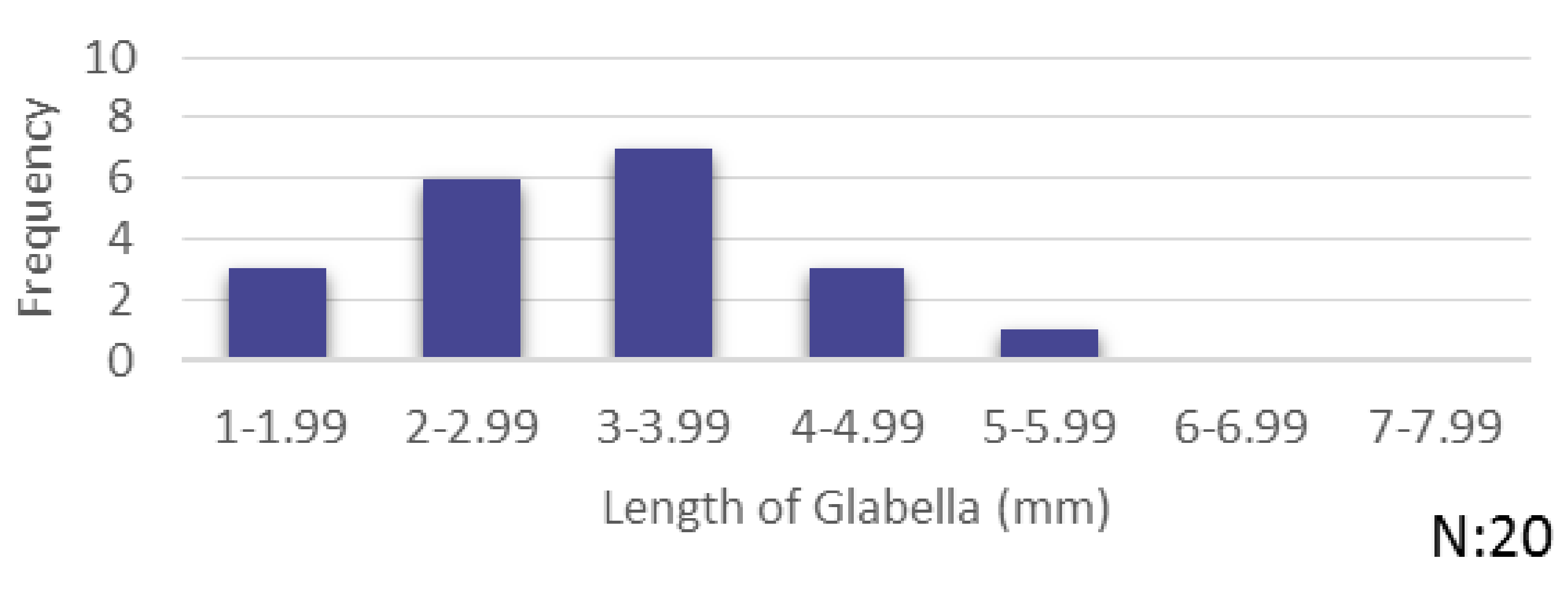

Triarthrus of the Antes Shale, Bellefonte, PA

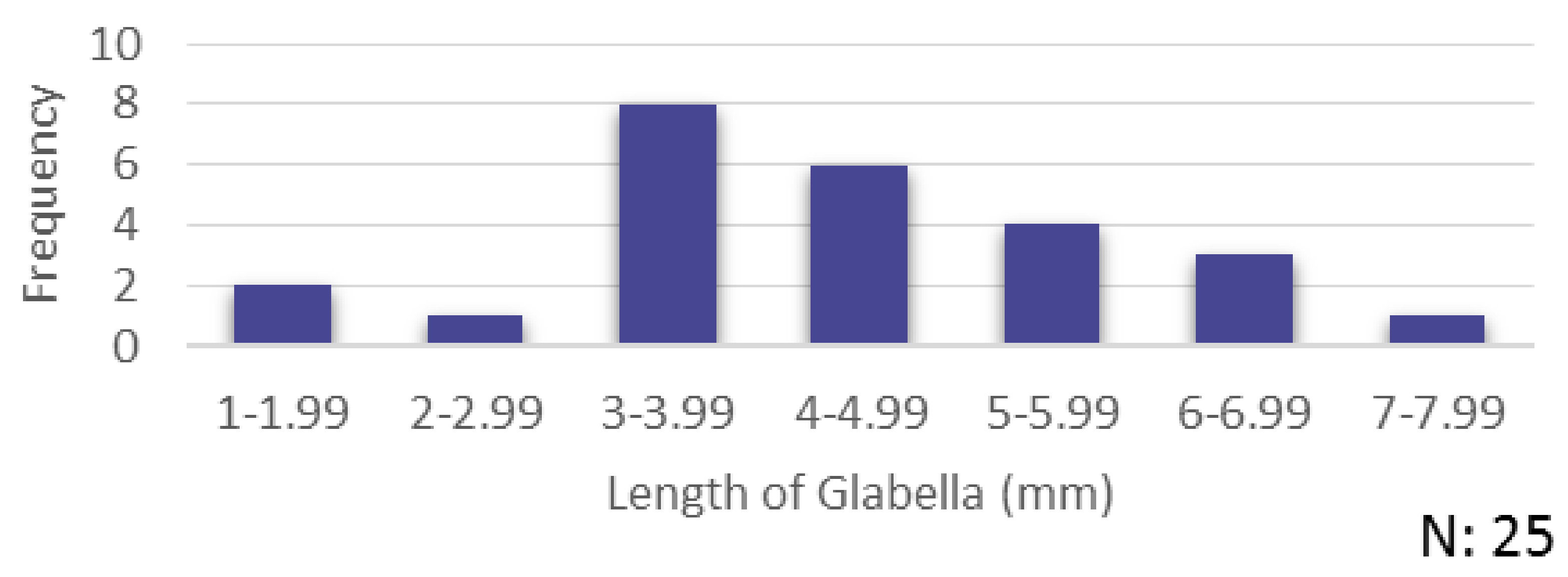

Figure 7: Glabellar lengths of Triarthrus from the Reedsville Formation at Swatara Gap, PA versus the Antes Shale at Bellefonte, PA. No corrections were made for deformation.

References

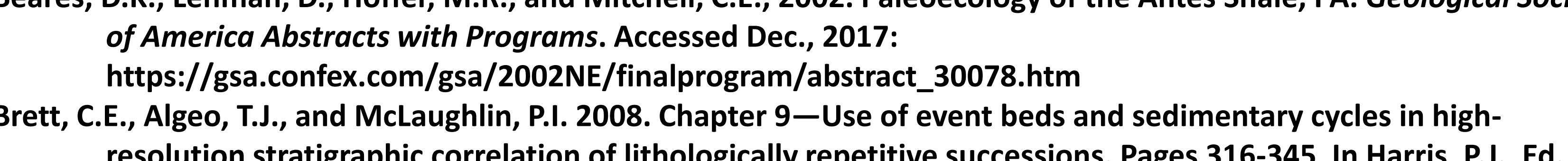

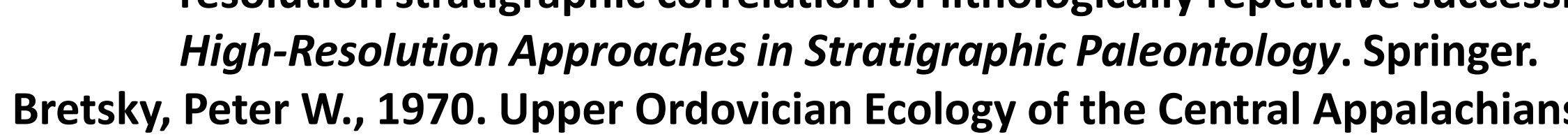

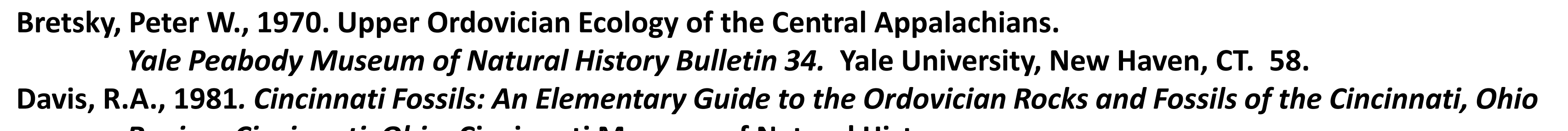

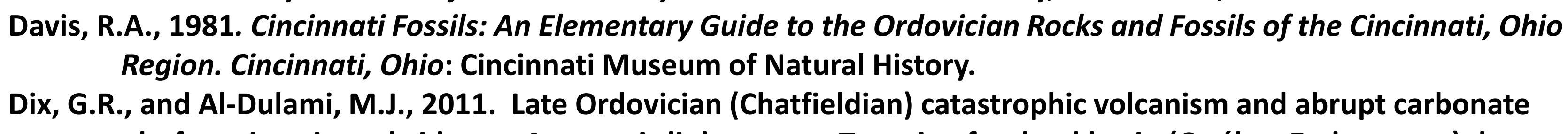

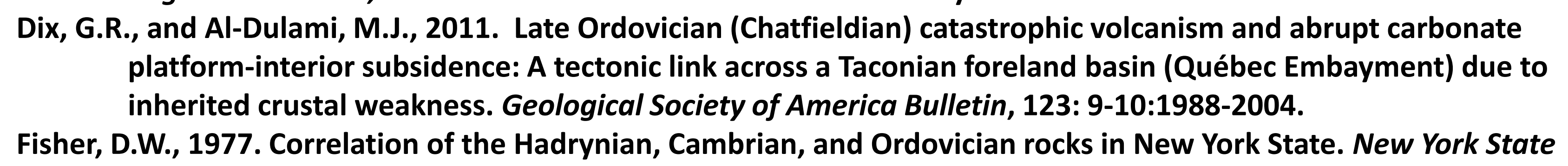
Fisher, D.W., 1977 . Correlation of the Hadrynin, Cambrian, and ordovicician rocks in New York State. New York State

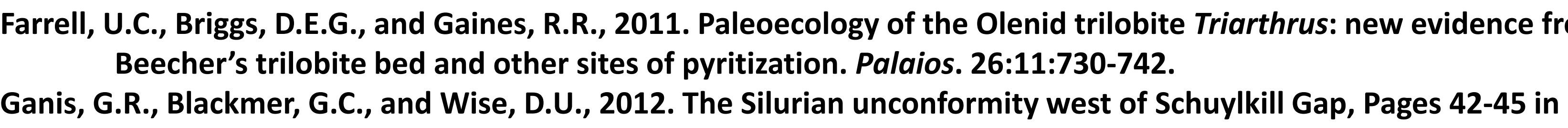

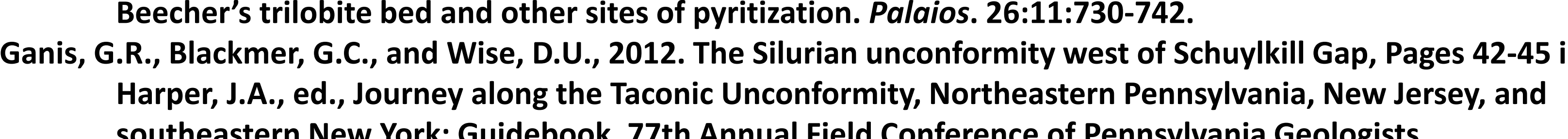

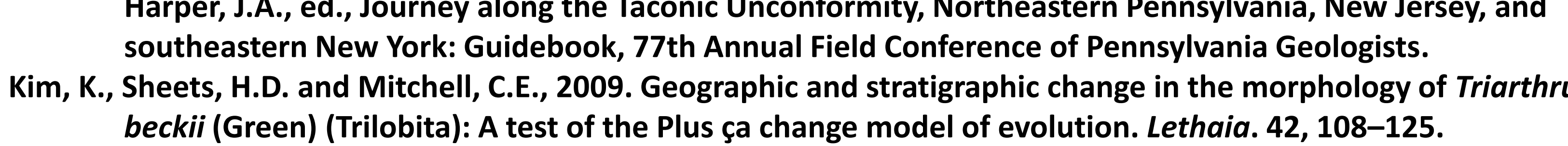

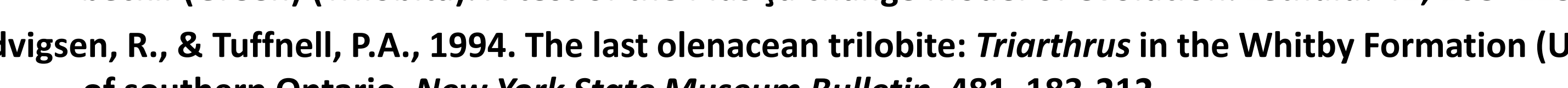

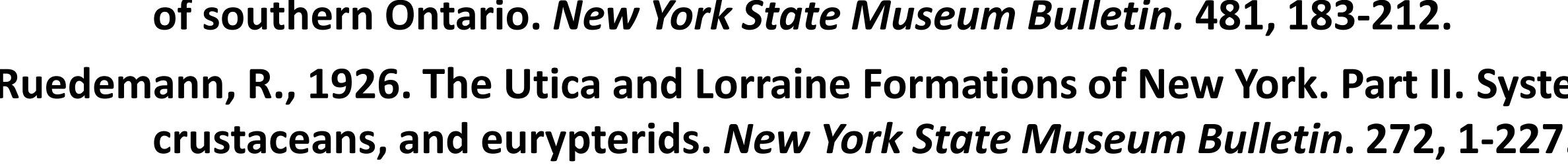

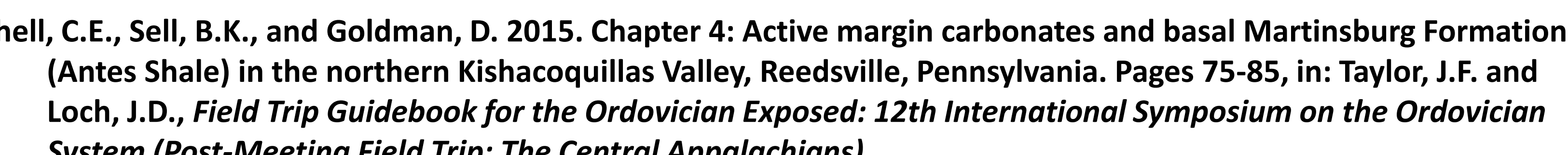

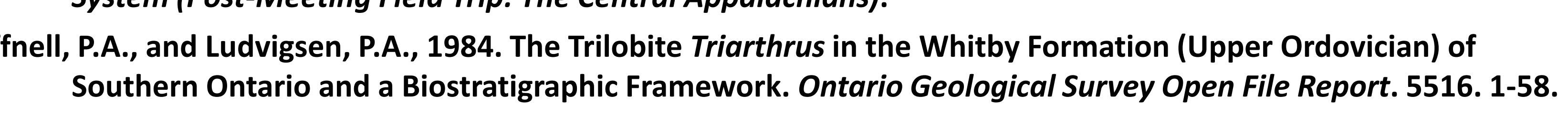

